\title{
Nuclear DNA content in the red conger eel Genypterus chilensis (Guichenot, 1881) (Actinopterygii: Ophidiidae)
}

\section{Contenido de ADN nuclear en el congrio colorado Genypterus chilensis (Guichenot, 1881) (Actinopterygii: Ophidiidae)}

\author{
Pedro Jara-Seguel ${ }^{1}$, Andrea Ubilla ${ }^{2}$, Juan Estrada ${ }^{3}$, Diego Ramirez ${ }^{3}$ \& Iván Valdebenito ${ }^{2}$ \\ ${ }^{1}$ Escuela de Ciencias Ambientales, Facultad de Recursos Naturales, Universidad Católica de Temuco, Casilla 15-D, Temuco, \\ Chile. \\ ${ }^{2}$ Escuela de Acuicultura, Facultad de Recursos Naturales, Universidad Católica de Temuco, Casilla 15-D, Temuco, Chile. \\ ${ }^{3}$ Centro de Investigación Marina Quintay (CIMARQ), Universidad Andrés Bello, Quintay. \\ *E-mail: ivisler@uct.cl
}

\begin{abstract}
Studies about nuclear DNA content in the genus Genypterus are scarce, and the present study gives the first estimate of nuclear DNA content of Genypterus chilensis, with a value of $2 \mathrm{C}=1.0 \pm 0.06 \mathrm{pg}$, value close to that obtained for other Ophidiidae species wich range between 1.2 and $1.68 \mathrm{pg}$.

\section{RESUMEN}

Los estudios sobre contenido de ADN nuclear en el género Genypterus son escasos, y el presente trabajo entrega por primera vez la estimación del contenido de $\mathrm{ADN}$ nuclear de Genypterus chilensis con un valor $2 \mathrm{C}=1,0 \pm 0,06 \mathrm{pg}$, valor cercano al descrito para otras especies de Ophidiidae que varían entre 1,2 y 1,68 pg.
\end{abstract}

Genypterus chilensis (Guichenot 1881) is an abundant fish species distributed along the coasts of the Southeastern Pacific Ocean. In Chile the species is distributed from Arica $\left(18^{\circ} \mathrm{S}\right)$ to Archipiélago de los Chonos $\left(47^{\circ} \mathrm{S}\right)$, with a bathymetric distribution between 20 and $150 \mathrm{~m}$. At present, the available biological studies on $G$. chilensis include parasitism, population dynamics, and temporal variation of the diet, reproductive cycle, and DNA-microsatellite characterization (Vergara \& George-Nascimento 1982; Paz 1991; George-Nascimento et al. 2004; Chong et al. 2006; Chong \& González 2009; Canales-Aguirre et al. 2010). However, cytogenetic data on $G$. chilensis are not available and basic aspects such as nuclear DNA content remain unknown.

In a recent survey on cytogenetic studies of Chilean fishes, 27 species were registered with data on chromosome number, karyotype morphology and/or nuclear DNA content (García 2010). This number of studied species represents ca. $2.7 \%$ of the fish Chilean diversity. It is remarkable, that data on nuclear DNA content are only available for the freshwater Trichomycterus areolatus Valenciennes 1846 (Trychomycteridae), Galaxias maculatus (Jenyns 1842) and Galaxias platei Steindachner, 1898 (Galaxiidae) (Colihueque et al. 2006; Jara-Seguel et al. 2008a, 2008b), while for the marine fishes only Sardinops sagax (Jenyns 1842) (Clupeidae) and Genypterus blacodes (Schneider 1801) (Ophidiidae) have been examined (Hardie \& Hebert 2004).

In order to increase the cytogenetic data of the Genypterus genus, the goal of this work is to estimate for the first time the nuclear DNA content of Genypterus chilensis that inhabits the Chilean coast.

Individuals of Genypterus chilensis were collected from

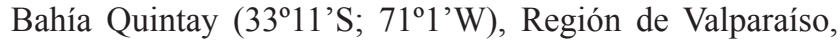
Chile. These specimens were maintained in hatcheries at the Centro de Investigaciones Marinas Quintay (CIMARQ; Universidad Andrés Bello). Measurements of nuclear DNA content (2C-values) were done by Feulgen microdensitometry in erythrocyte smears, using the software Nis-Elements (Nikon, Yokohama, Japan). Blood samples were taken from the caudal vein of three specimens, and 100 erythrocyte nuclei were analysed for each of them (300 cells in total). To estimate $2 \mathrm{C}$ DNA content the cytological 
and microdensitometrical method described in detail by Jara-Seguel et al. (2008a; 2008b) in erythrocyte nuclei of Galaxias species (Galaxiidae) was followed. In this method the software estimates values of integrated optical density (IOD) of each erythrocyte nuclei, and the 2C-value is then obtained by comparison with erythrocyte smears of Oncorhynchus mykiss (Walbaum, 1792) used as standard $(2 \mathrm{C}=5.5 \mathrm{pg}, 2 \mathrm{n}=58-62$ chromosomes) (Carvalho et al. 2002).

The $2 \mathrm{C}$-value estimated in erythrocytes of $G$. chilensis was $1.0 \pm 0.06 \mathrm{pg}(\mathrm{IOD}=19.32 \pm 1.24$ arbitrary units $)$ and the coefficient of variation was of $6.4 \%$. According to these results, the $\mathrm{C}$-value of $G$. chilensis is $0.5 \mathrm{pg}$. The mean IOD for the standard $O$. mykiss was $107.0 \pm 4.02$ arbitrary units $(2 \mathrm{C}=5.5 \mathrm{pg})$. G. chilensis showed a $\mathrm{C}$-value near to its sister species G. blacodes $(0.6 \mathrm{pg})$ and to co-familial members previously studied [Ophidion scrippsae (Hubbs, 1916), O. welshi (Nichols \& Breder 1922), Sirembo imberbis (Temminck \& Schlegel, 1846)] (Table I). Thus, the range of C-values described for Ophidiidae vary between 0.5 and $0.84 \mathrm{pg}$ (mean $0.65 \pm 0.12 \mathrm{pg}$ ) being lower to the average $1.2 \mathrm{pg}$ documented for Teleost fishes. However, the $\mathrm{C}$-value of $G$. chilensis is within the range recorded for Teleosts (Cvalue from 0.4 to $4.4 \mathrm{pg}$ ) (Gregory et al. 2006).
In general, in teleost fish there is little variation in basal genome size and alterations in C-value ordinarily appear to have resulted from the accretion and/or deletion of small blocks of DNA(Gregory \& Hebert 1999). However, although these alterations may modify the karyotype structure (Takai \& Ueno 1997), Robertsonian traslocations are the most important mechanisms of chromosome evolution in fishes (Vitturi \& Catalano 1988; Winkler et al. 2004). Karyotype studies in Genypterus species have not been carried out, and represent a pending task for the near future.

In fishes, estimations of C-values have increased in recent decades and this is by far the best represented group in the current databases on the subject with ca. 1,300 examined species (Gregory et al. 2006; Smith \& Gregory 2009). Genypterus species are important as a food resource, being currently obtained by artisanal fishing methods. Because of over fishing, a reduction of their population has been observed. Consequently, aquaculture programs have begun farm production of this species, for which genome data can be important to its improvement and management (Martínez 2005). The present work supplies valuable data on C-value for this teleost fish, thus increasing the framework on cytogenetic information for Ophidiidae species inhabiting in Southeastern Pacific Ocean and showing a wide distribution in Chilean coasts.

TABLE 1. Nuclear DNA content (C-Value) for Genypterus chilensis and others Ophidiidae species.

TABLA 1. Contenido de ADN nuclear (valor C) para Genypterus chilensis y otras especies de Ophidiidae.

\begin{tabular}{lll}
\hline Species & C-value $(\mathrm{pg})$ & Reference \\
\hline Genypterus chilensis & 0.5 & Present work \\
G. blacodes & 0.6 & Hardie \& Hebert (2004) \\
Ophidion scrippsae & 0.68 & Hinegardner (1968) \\
O. welshi & 0.84 & Hinegardner \& Rosen (1972) \\
Sirembo imberbis & 0.63 & Hardie \& Hebert (2004) \\
Teleost fishes (average) & 1.2 & Gregory et al. (2006) \\
\hline
\end{tabular}

\section{ACKNOWLEDGEMENTS}

Financed by projects FONDEF D06I1024 y D06I1020.

\section{REFERENCES}

Canales-Aguirre, C., Ferrada, S., Hernández, C. \& Galleguillos, R. 2010. Usefulness of heterologous microsatellites obtained from Genypterus blacodes (Schneider 1801) in species Genypterus of Southeast Pacific. Gayana 71(1): 74-77.
Carvalho, M., Oliveira, C., Navarrete, M., Froehlich, O. \& Foresti, F. 2002. Nuclear DNA content determination in Characiformes fish (Teleostei, Ostariophysi) from the Neotropical region. Genetics and Molecular Biology 25(1): 49-55.S).

Chong, J., Sepúlveda, K. \& IbÁÑez, C. 2006. Variación temporal en la dieta del congrio colorado, Genypterus chilensis (Guichenot, 1881) frente al litoral de Talcahuano, Chile (36 $32^{\prime}$ S $-36^{\circ} 45^{\prime}$ S). Revista de Biología Marina y Oceanografía 41(2): 195-202.

Chong, J. \& GonzÁlez, P. 2009. Ciclo reproductivo y talla media de madurez del congrio colorado, Genypterus chilensis 
(Guichenot, 1881) en el litoral de Talcahuano, Chile. Revista de Biología Marina y Oceanografía 44(1): 257262.

Colihueque, N., Corrales, O. \& Parraguez, M. 2006. Karyotype and nuclear DNA content of Trichomycterus areolatus (Siluriformes: Trichiomycteridae). Genetics and Molecular Biology 22(2): 278-282.

García, M. 2010. Antecedentes citogenéticos sobre peces nativos de Chile: Avances y aplicaciones. Tesis de Licenciatura en Recursos Naturales, Universidad Católica de Temuco. 39 pp.

George-Nascimento, M., Lobos V., Torrillos C. \&. Khan, R. 2004. Species composition of assemblages of Ceratomyxa (Myxozoa), parasites of lings Genypterus (Ophidiidae) in the Southeastern Pacific Ocean: an ecomorphometric approach. Journal of Parasitology 90(6): 1352-1355.

Gregory R. \& Hebert P. 1999. The modulation of DNA content: Proximate causes and ultimate consequences. Genome Research 9: 317-324.

Gregory, R., Nicol, J., Ta mm, H., Kullman, B., Kullman, K., Leitch, I., Murray, B., Kapraun, D., Greilhuber, J. \& BennetT, M. 2006. Eukaryotic genome size databases. Nucleic Acids Research 35: 332-338.

Hardie, D. \& Hebert, P. 2004. Genome-size evolution in fishes. Canadian Journal of Fisheries and Aquatic Sciences 61: 1636-1646.

HinEgardner, R. 1968. Evolution of cellular DNA content in teleost fishes. American Naturalist 102: 517-523.

Hinegardner, R. \& Rosen, D. 1972. Cellular DNA content and the evolution of teleostean fishes. American Naturalist 106: 621-644.
Jara-seguel, P., Valdebenito I., Palma-Rojas, C. \& Rebolledo, C. 2008a. Nuclear DNA content in Galaxias maculatus (Teleostei: Osmeriformes: Galaxiidae). Latin American Journal of Aquatic Research 36(1): 87-91.

Jara-Seguel, P., Valdebenito, I. \& Palma-Rojas, C. 2008 b. Contenido de ADN nuclear en Galaxias platei (Teleostei: Osmeriformes: Galaxiidae). Gayana 72(2): 196-201.

Martínez, P. 2005. Aplicaciones de la genética para la mejora de la acuicultura. Boletín del Instituto Español de Oceanografía 21(1-4): 225-238.

PAZ, C. 1991. Dinámica poblacional del recurso congrio colorado Genypterus chilensis (Guichenot, 1848), frente a las costas de Coquimbo. Tesis de Biología Marina, Universidad Católica del Norte, Coquimbo, 76 pp.

Smith, E. \& Gregory, R. 2009. Patterns on genome size diversity in the ray-finned fishes. Hydrobiologia 625: 1-25.

TAKaI, A. \& Ueno K. 1997. Karyotypes and chromosomal distribution of constitutive heterochromatin and nucleolus organizer regions in three kyphosid fish (Perciformes). Cytobios 89: 141-148.

Vergara, L. \& George-Nascimento, M. 1982. Contribución al estudio del parasitismo en el congrio colorado, Genypterus chilensis (Guichenot, 1848). Boletín Chileno de Parasitología 37: 9-14.

Vitturi, R. \& Catalano, E. 1988. Karyotypic variability associated with robertsonian fusion in two species of the family Ophidiidae (Pisces, Perciformes). Italian Journal of Zoology 55(1): 55-58.

Winkler, F., Garcia-Melys D. \& Palma-Rojas C. 2004. Karyotypes of three South East Pacific flounder species of the family Paralichthyidae. Aquaculture Research 35: 1295-1298.

Recibido: 05.06.11

Aceptado: 24.08.11 